\title{
Human-animal relations beyond the zoo: the quest for a more inclusive sustainability education
}

Hanna Sjögren, Per Gyberg and Malin Henriksson

\section{Linköping University Post Print}

\section{Tweet}

N.B.: When citing this work, cite the original article.

This is an electronic version of an article published in:

Hanna Sjögren, Per Gyberg and Malin Henriksson, Human-animal relations beyond the zoo: the quest for a more inclusive sustainability education, 2015, Pedagogy, Culture \& Society, (23), 4, 597-615.

Pedagogy, Culture \& Society is available online at informaworld ${ }^{\mathrm{TM}}$ :

http://dx.doi.org/10.1080/14681366.2015.1081969

Copyright: Taylor \& Francis (Routledge)

http://www.routledge.com/

Postprint available at: Linköping University Electronic Press

http://urn.kb.se/resolve?urn=urn:nbn:se:liu:diva-125527 


\section{Human-animal relations beyond the zoo: the quest for a more inclusive sustainability education}

Hanna Sjögren (corresponding author)

Department of Thematic Studies - Unit of Technology and Social Change, Linköping University, Linköping, Sweden

Hanna Sjögren

Tema $\mathrm{T}$

Linköping University

58183 Linköping

Sweden

Phone: +46 31282178

Mobile: +46 702879425

E-mail: hanna.sjogren@liu.se

Per Gyberg

Department of Thematic Studies - Unit of Environmental Change, Linköping University, Linköping, Sweden

Per Gyberg

Tema M

Linköping University

58183 Linköping

Sweden

Phone: +46 708364990

E-mail: per.gyberg@liu.se 


\title{
Malin Henriksson
}

Department of Thematic Studies - Unit of Technology and Social Change, Linköping University, Linköping, Sweden

Malin Henriksson

Tema T

Linköping University

58183 Linköping

Sweden

Phone: +46 704856919

E-mail: henrikssonmalin@yahoo.se

\begin{abstract}
This paper investigates human-animal relations in sustainability education. To understand what educational relationships and boundaries are challenged and/or strengthened in education promoting future sustainable societies, we argue that educational theory and practice must move beyond the anthropocentric framework's sole focus on relationships between humans. Drawing on focus group interviews with teacher instructors at eight Swedish universities, we discuss cases in which sustainability education benefits from being understood as crafted via human-nonhuman relations. By concentrating on human-animal relations, we discuss the political and ethical implications arising from relationships being created in certain ways and not others. The empirical examples illustrate how the relations between teacher instructors and various animals can be a critical starting point for understanding the limitations and possibilities fostered by sustainability education.
\end{abstract}

Keywords: human-animal relations; feminist posthumanities; sustainability education; focus groups 


\section{Human-animal relations beyond the zoo: the quest for a more inclusive sustainability education}

\section{Introduction: beyond the zoo}

We are approaching the end of the United Nations Educational, Scientific and Cultural Organization’s (UNESCO’s) 2005-2014 Decade of Education for Sustainable

Development, whose very ambitious goal has been for all education and teaching to foster knowledge 'that motivate[s] and empower learners to change their behaviour and take action for sustainable development’ (UNESCO 2013). It remains a challenge, however, to imagine how education can promote more sustainable futures and to determine what futures we should imagine and create through education (McNaughton 2010). Who is educable in and for such futures (Pedersen 2010a)? The ecological and political crises addressed by this UNESCO initiative require theoretical and methodological approaches that avoid recreating what have often been problematic divisions between nature and culture, human and animal, subject and object, and teacher and student.

Education is considered an important arena when addressing matters associated with sustainability and the environment (Gough and Scott 2008; Kahn 2003). Education is also an arena in which questions concerning what knowledge is and what sort of knowledge is valid are negotiated in the intersection between various practices (e.g. global and national educational objectives) and within and across everyday school practices. We argue that these negotiations play a significant role in identifying the objects and subjects considered important in education. Contemporary ecological crises require an educational approach that can elucidate the fact that human and animal bodies are intertwined in various ways with natural and environmental processes (for discussion of this, see, e.g., Alaimo [2010]). Western education can be said to play a 
crucial role in sustaining and legitimating the separation of humans from nonhumans (Pedersen 2010b, 241). Education as 'the project of "the human”' (Pedersen 2010b, 243) is based on an idea that creates metaphorical and literal fences from which we can observe, measure, define, control, and - most importantly - separate nature from ourselves. 'Efforts to travel into "nature" become tourist excursions that remind the voyager of the price of such displacements - one pays to see fun house reflections of oneself' (Haraway 1992, 296). In this sense, nature becomes a zoo, a place where it is possible to control and adapt nature to human conditions.

We will use zoos to symbolize the intertwining of education, animals, and humans. At best, schools and zoos are environments where humans learn about the surrounding world. At school, dedicated teachers use creative methods to teach children to become moral and caring beings. At the zoo, up-close-and-personal experience with animals is intended to evoke a desire to care about the environment and the preservation of endangered species and ecosystems (Brando and Lynning Harfeld 2014). Zoos can also be described as places of confinement, repositories for unhappy, caged, meant-tobe-wild animals displayed for the human gaze. Likewise, schools with insufficient resources, indifferent teachers, and rigid rules are repeatedly described as prisons - or zoos - for students. Scholars in critical animal studies, however, argue that relationships between humans and animals are never innocent but always hierarchical (Best et al. 2007; Weisberg 2009; Pedersen 2010b; Nocella et al. 2014). For example, as Brando and Lynning Harfeld (2014) point out, zoos are places where we not only watch animals but also eat them. In Sweden, this dilemma is highlighted in heated political debate about whether schools should provide vegetarian food or even have 'meat-free school days’ (see, e.g., Kjöller [2012]; Olsson [2012]; Drevfjäll [2013]). The eating of others nonhuman animals, plants, and bacteria - changes us as humans both materially and 
discursively. The often problematic relationship between nonhumans and humans, exemplified in the debate about meat-free days, raises questions concerning ethics, responsibility, and subjectivity in an educational context.

This article investigates how responsible positions are made possible in humananimal relations in the education context. We will demonstrate why relationships between human and animal bodies can be regarded as both relevant to and interesting for education. The discussion will be developed using a feminist posthumanities approach to education. We argue that combining feminist posthumanities and educational philosophy helps make education comprehensible in today’s society, enabling us to envision sustainability education incorporating human-animal relations beyond the zoo. By concentrating on ethical positions and boundaries between human and nonhuman bodies, we examine the knowledge such relationships create and the inclusions and exclusions they enable. The processes through which human-animal relationships and boundaries are challenged, negotiated, and legitimized are of considerable importance when seeking to understand how responsibility is made possible and what knowledge is viewed as legitimate.

\section{A feminist posthumanities approach}

The criticism of anthropocentrism, in which humanity is considered the centre of reality, has attracted attention in what has been labelled the 'posthuman turn' that has occurred across several disciplinary fields. The common denominator of the posthumanities is its critique of anthropocentric approaches, instead arguing for nonhuman agency and the recognition of nonhuman animals, the environment, objects, and technology in social theory (Badmington 2004; Åsberg 2012). In the present article, we view critical posthumanities as continuing the feminist critique and theorizing of 
how various others (e.g. women, indigenous people, and animals) are 'othered' in relation to specific norms of what a human is - norms often based on the 'perfected' white, healthy, educated man.

Feminist theorist Braidotti (2013) has strikingly demonstrated the limited usefulness of humanism when it comes to understanding today’s ecological, political, and technical challenges. She writes that the idea of the human is based on a specific norm of what human means by 'transposing a specific mode of being human into a generalized standard, which acquires transcendent values as the human: from male to masculine onto human as the universalized format of humanity' (Braidotti 2013, 26). Our take on the posthumanities is in line with feminist discussions of the term (Åsberg, Koobak, and Johnson 2011). Feminist theorists traditionally involved in deconstructing the nature/culture divide in terms of gender and sex have also come to consider categories such as race, class, sexuality, functionality, and nonhuman animals and ‘earth-others’ (Lykke 2009, 2010; Birke 2012). Feminist theorists have long noted that the separation of 'human' (as culture) from 'nature' (free of culture) has allowed for a whole range of problematic knowledge practices and otherings of all those not fitting in the too narrow category of culture. Feminist environmentalists such as Alaimo (2010) have advocated understanding that nature is not 'out there' but always already in ourselves. In addition, animals, plants, genes, and bacteria are involved in reading and de/coding the world. Literacy, and writing, can come in many forms and cannot be ascribed to humans alone, DNA codes being one illustrative example. In other words, the idea of humans as the only literate creatures ignores the agency and importance of the non-human world.

\section{Beyond the zoo in education}


The quest for sustainability in the educational sphere problematizes the anthropocentric assumptions embedded in most conventional educational theory, practice, policy, and research (Pedersen 2010b). Biesta (2006a) has criticized humanism from within the educational sciences, arguing that it entails entrenching who the educable subject is before relating this subject to others. According to Biesta (2006a, 15), ${ }^{1}$ modern education is based on a close association between rationality, autonomy, and education, which together form the 'Holy Trinity of the Enlightenment project'. Positing what it means to be human therefore creates exclusions that hinder any understanding of subjectivities beyond the idea of the human. Such exclusions can be regarded as unsustainable in light of the ecological crises addressed under the umbrella term of sustainable development, as an anthropocentric perspective risks incurring devastating consequences for both human and nonhuman life (Hinchliffe et al. 2005, 43). Anthropocentric perspectives place human activity and survival at the centre of sustainability issues (Alaimo 2012). As a result, the ecological systems, of which humans are part, are seen as passive and under human control. Biesta (2006a, 19) holds that 'the challenge to overcome humanism is also a crucial challenge for education'. Posthumanities thought offers the initial elements of such a project by emphasizing that humans too are animals that have 'coevolved with various forms of technicity and materiality, forms that are radically "nonhuman” and yet have nevertheless made the human what it is’ (Wolfe 2010, xxv). Several scholars criticize how contemporary understandings of scientific literacy and knowledge produced through education

1 Citations of and quotations from Biesta (2006a) refer to our translations of passages from the Swedish version of his book Beyond Learning: Democratic Education for a Human Future (see, e.g., Biesta [2006b]). 
normalize certain power relations between human and nonhuman animals (Solot and Arluke 1997; Kahn 2003; Pedersen 2007). Furthermore, they have delineated what a posthumanities approach can contribute to educational theory and practice (Gough 2004; Pedersen 2010a,b; Hultman and Lenz Taguchi 2010; Bodén 2013). Pedersen (2010a, 689) holds, for example, that posthumanities approaches can be helpful in expanding the anthropocentric focus of education and teaching, for example, by embracing 'multi-species-oriented ethical literacy'. By referring to Levinas, Biesta (1999) reaches a similar conclusion. He wants to reinvent the subject, not as a what, but as a who to pinpoint the subject 'as a singular being' (Biesta 1999, 209); this being comes to matter through the questions imposed through action, which demands a (moral) position by the being (216). Biesta (1999) also claims that this 'who' is a 'question of space or location, because it raises the question where someone comes into presence' (209). This radical intersubjectivity provides a foundation that is not limited to humans but takes every being's becoming into account. From this standpoint, education is about creating not autonomous and self-governing individuals but moral beings. According to Biesta (2006a, 69), education should promote 'the commonality of those who do not have anything in common'. We want to concentrate on 'the questions that are imposed' on the beings through actions (Biesta 1999, 209) in line with Karen Barad's (2003) idea of the importance of matter. We want to argue that these are the questions that entangle the (ontological) matter with the (epistemological) discourses/knowledge.

What is needed is a robust account of the materialization of all bodies “human” and “nonhuman” - and the material-discursive practices by which their differential constitutions are marked. This will require an understanding of 
the nature of the relationship between discursive practices and material phenomena, an accounting of “nonhuman” as well as "human” forms of agency, and an understanding of the precise causal nature of productive practices that takes account of the fullness of matter's implication in its ongoing historicity. (Barad 2003, 810)

From an epistemological perspective and in a very broad sense, entities are performative in three ways: (1) latent, (2) considered, and/or (3) forced. There are always latent matters, always entities that are discursively excluded but that matter beyond the sphere of knowledge in a certain practice. Some matters of the entities are discursively considered, or included. These are usually taken for granted and there is a very clear idea of how these entities behave. When an entity matters unexpectedly and outside the frames, when a being intrudes and forces itself to matter, it has the potential to change discourses/knowledge. Discourses/knowledge can be changed in 'the zone of proximal development' or they will pass unnoticed, be explained as unexplained or unexplainable (cf. Vygotsky, 1994, p. xxxv). Matter that is latent or forced on knowledge/discourses could be actively used in education to problematize established norms and positions.

Haraway $(2008,71)$ holds that the capacity to respond is created in and for 'multidirectional relationships, in which always more than one responsible entity is in the process of becoming'. Such a view of relationships is associated with the possibility of responding in the world in which we share situations and events. The possibility of responding can have significant consequences for the potential to form responsible relationships and sustainable societies through education. The question of who is responsible for creating a more sustainable society is as important as it is difficult. A posthumanities and educational discussion of responsibility, ethics, and subjectivity is 
what ties together the discussions presented here.

\section{Materials and methods}

The empirical material in this article is drawn from focus group interviews with teacher instructors at eight Swedish universities. Teacher instructors are given central responsibility for educating future generations of teachers. The multifaceted position of the teacher instructor is central to this study, as the teacher instructor is located in the intersection of school practices, university education, and educational reforms. This position permits active reflection on who the future teacher should be and what the future teacher should know. In total, 34 teacher instructors participated in the eight focus groups. Focus groups were particularly useful for this research as they are said to

constitute ‘thinking societies in miniature' (Jovchelovitch, as quoted by Wibeck, Dahlgren, and Öberg 2007, 250). This is partly because they let participants question each other, allowing group dynamics to take the discussion in unexpected directions (Kitzinger and Barbour 1999, 4; Wibeck 2010, 52). Based on the transcribed discussions, we have approached the issue of what boundaries are challenged and/or established through the focus group discussions.

The focus group interviews covered a range of topics related to the broad theme of sustainability in educating future teachers. For example, questions were raised about the Swedish school curriculum, a document that emphasizes sustainability in numerous places without actually defining it, in terms of both general and course-specific objectives (Skolverket 2011). We aimed to capture the potentially changing ways in which sustainability issues might impinge on the education of future teachers. The focus group interviews were transcribed for analysis, which began with repeated readings and coding for patterns and themes. Of particular concern was identifying instances in 
which relationships between humans and nonhumans were ascribed and challenged. It is the moments of boundary crossing and erasure that illuminate the conditions under which nonhuman subjectivity can be included in education intended to foster a sustainable society.

\section{Individuality as a limited condition for responsible knowledge}

Across several focus groups, the number of nonhuman animals, in relation to the number of group participants, appeared to be important in ordering knowledge of the nonhuman Other. The following excerpt, in which participants reflect on why it seems to be acceptable to kill animals that are part of a collective, illustrates how this knowledge was articulated:

André: They [i.e. ants and spiders] are certainly okay to kill ... but then [someone] has written about [this] among other things, and it is also very fascinating that we think certain animals are okay to kill ... so there we have no moral doubts.

Anna: No ... there are so many ants that it ... ((several laughs)) Those Burgundy snails are fun as well when the first one or two show up, then you can build a house for the snails and watch.

André: Yes

Anna: But then it gets full and then you throw them away. In the preschool yard they are everywhere and they are disgusting - [we] throw them out and they break.

Hanna: Okay

Anna: I have done that myself. ((laugh)) It is a nice development ((laugh)) to start off 
by taking care of the little snail and then ...

The contrast between the few snails ('one or two') that Anna first encountered at the preschool and the increasing numbers that later give her a sense that they are 'everywhere' reveals that the transition from caring to killing can be swift. As Anna points out, when snails are 'everywhere' in the school yard, they become 'disgusting'. In this example, it is the number that becomes significant for negotiating the humannonhuman boundaries and, ultimately, for determining what lives are important, that is, who - or what - should live and who should die.

What is evident in the extract is that when the individual Burgundy snail is transformed into collective snails, human-nonhuman relations are reshaped for the teacher educators: the snail is first met face-to-face and later confronted as a faceless collective. Identifying this process of reshaping relations emphasizes the malleability and mutability of the boundaries we create around nature/culture and human/nonhuman. Relationships do not have intrinsic qualities; instead, they create various affects depending on specific compositions. It is precisely through Anna's initial relationship with the specific, particular snail - which suddenly found itself in the preschool yard that the pedagogical practice creates the possibility of treating the snail as an entity that the preschool teachers can care about. When the factual, material quantity in the room is changed, the relationship is also changed. This affects the delicate question of who - or what - should live and who should die.

To draw on the language of the philosopher Buber (1970), one can understand that the relationship between Anna and the Burgundy snail shifts from I-You to I-It. Buber uses this nomenclature to argue that an ethical encounter does not require 
categorizations and knowledge. Buber claims that the passive encounter, i.e. one that is not sought, presents an opportunity to enter into a directly ethical relationship with the You. At the same time, this relationship is fragile and risks being transformed into an IIt relationship (Buber 1994, 129). As is evident in the focus group discussion, once the Burgundy snails arrive in greater numbers, the specific I-You encounter is rendered impossible. The relationship changes and the Anna-Burgundy snail relationship is transformed from an I-You to an I-It relationship. In the encounter between Anna and the Burgundy snails, it is when the snails form a collective that the ethically possible relationship suddenly disappears. When the snail population grows - from one or two to many - the relationships change in kind.

This transition in the Anna-Burgundy snail relationship can be further illuminated by turning to the metaphor of the zoo in modern society. Willis (1999) compares the organization of the zoo to that of a garden, writing that 'the brutal reality of the garden is beauty achieved on the basis of exclusion and death' (672). Marino, Bradshaw, and Malamud (2009) draw attention to the brutal logic of the zoo: learning to care for a certain species requires the captivity and sacrifice of individual animals (IYou) in order to save a species consisting of a collective of animals (I-It). The captivity of one animal is considered justified in order to feel and to understand that their kin need not be harmed. This logic legitimates the idea that humans need to see and touch an individual animal to develop an ethical relationship with and a sense of responsibility for the species of that animal.

One can interpret the transition between the specific and general as occurring when the species of snail becomes unmanageable and beyond human control, care for individuals being rendered impossible. It seems as though it is only in the setting of 
manageable control that the animal can be cared for. The relationship between snails and preschool teachers addressed in the interview can be placed in the context of the snail's factuality (i.e. presence, reproductive patterns, and ecosystem) and discourses concerning the snail in preschool, including children's songs such as Lilla snigel akta dig ('Little snail watch out') and the children’s programme Björnes magasin ('The bear's magazine'), whose main character is always in the company of a snail. The relationship between the Burgundy snails in the preschool yard and the teachers and children at the preschool creates effects that are both discursive and material, the snails being understood both as individuals (with their cultures of houses) and as a collective (i.e. an infinite natural resource). As we can see above, the boundary between individual and collective has consequences in terms of whose lives - or what lives - are rendered significant. As long as the animal is delimited within a manageable zoo setting, care seems possible.

While snails resonate positively in Swedish popular culture, they are still an animal easily dismissed as 'Other' by teacher educators, as the focus group interview discussion demonstrated. In this respect, the snail can be seen as occupying a lower rung on a human-centric animal hierarchy that ranks animals based on various criteria, including their sociocultural status. This human ranking of animals, and how such ranking informs human relations with animals, is illustrated in the following extract:

Sandra: I usually go around with two demonstration placards.

Sofia: Yes

Sandra: And they say things like "Save the panda". Who wants to come along

Sofia: Yes 
Sandra: to town now? There are a lot of people out to save

Sofia: Everyone agrees on that.

Sandra: the panda, since pandas are such cute symbols. Later, I usually show the other placard: "Who wants to save the tick"?

Solveig: Surely, they don’t need saving? ((laughter))

In the contrast between the cute pandas and what the quoted group member does not find worth saving, i.e. the tick, one can see how boundaries are drawn in humannonhuman relations. The panda referred to in the placard becomes, thanks to its iconic status, an individual in the relationship. The relationship with the tick, which Sandra addresses in the second placard, is understood and created differently. In the contrast between the two species, the panda appears to be an individual worthy of attention, while the tick becomes the opposite. The making of the relationship has consequences for - and is connected with - sociocultural practices such as the use of the tick in commercials for tick-borne encephalitis vaccine and the use of the panda in the World Wide Foundation’s (WWF) logotype promoting a better world.

As the conversation between Sandra, Sofia, and Solveig continued, they contemplated whether all species are truly worth saving. Solveig asserted that while one of the species is threatened with extinction (the panda), the other continues to multiply (the tick). Once again individuality in the human-animal relationship is made relevant as an important criteria for deciding who is worthy of living. The pedagogical point that Sandra wants to make, with the help of her placards, elucidates just how the relationships between human and nonhuman animals create various boundaries 
affecting who is and is not considered worthy. The role of individuality raises further questions about the possibility of ethical relations through education. A premise of the zoo is that 'prolonged suffering of confined animals balances out the effort to save their counterparts in the wild' (Marino, Bradshaw, and Malamud 2009, 27). Ethical questions in the realm of sustainability need to consider both individuals and their collectives. Learning to care for just one individual cannot really be considered a sustainable ethical practice.

\section{Reterritorialization as a limited condition for responsible knowledge}

Another significant criterion for determining how knowledge is ordered in the focus groups is reterritorialization, using this concept and that of deterritorialization in line with Colebrook (2010, xix) and Heise (2008, 51). Drawing on Appadurai’s anthropological work on how experiences of place change under the influence of modernization and globalization, Heise (2008) holds that deterritorialization 'refers to the detachment of social and cultural practices from their ties to place' (51). Colebrook (2010, xix), in her reading of Deleuze and Guattari, holds that the forces that create possible becoming (i.e. territorialization) can also create the opposite, the impossibility of becoming (i.e. deterritorialization). These concepts verbalize how relationships are arranged and changed with each material and discursive component.

Individuality, as described above, was criticized in certain focus groups as a 'double standard', which some participants felt that the student teachers expressed when inclined to care about a specific nonhuman individual. The following discussion is based on illustrations that we showed to the participants to stimulate discussion (see, e.g., Wibeck [2010, 78]). One image depicted an excavator filled with dead pigs, similar to the pictures often used in animal rights movement campaigns against the meat 
industry (cf. Redmalm [2011]):

Olga: There are few things that have upset our students as much as visiting the [agricultural school], where a group, in one instance, was there when they found a small piglet that had died because the mother had lain on it. And I can’t tell you how long they talked about it.

Olof: What are you saying?

Olga: I am talking about how incredibly dreadful it was, and the animal welfare they have there is still very

Ove: Exemplary - sure.

Olga: Yes, exactly. And then they all eat meat, but they don't really seem to make the connection. Instead, it was just ... it was more of a discussion of maternal instincts that followed. It was such a dreadful incident. [said with sarcasm]

In the above exchange, participants criticize the transition between the collective and the individual. In Olga's reference to the student teachers, the criticism emanates from the fact that the students did not display concern for something that they were not encountering face-to-face We are thinking here of the pork chop or slice of bacon on the plate - as Olga insinuates - which can seem to be both near and far from the piglet that the student teachers encountered on their field trip to the agricultural school. That the students did not manage to connect the meat on the plate to the piglet crushed to death can be seen as a consequence of how knowledge is ordered in this context. When concern and responsibility arise within the relationship as an effect of the piglet's material and discursive position, limited responsibility is possible. That responsibility 
does not embrace all pigs that are born, live, and die under prison-like conditions. Within the relationship, knowledge is arranged so that pigs as a collective can be killed. The 'meat norms' (Gålmark 2005, 83) that make the eating of nonhuman bodies a nonissue, in which nonhuman animals are seen as a natural resource, are undeniably linked to the issue of who - or what - gets to live and who gets to die. Calvo (2008) sees the eating of certain animals as a norm produced through ideology: a social ordering of human relationships with nature separating human from animal life to justify the killing of certain animals (see also Nibert [2003]). Care seems to be possible because of how the pigs suddenly resemble us, and the discussion of the maternal instincts awakened by encountering the piglet strengthens this interpretation. The piglet is not understood as an Other here, but instead as one of us (Wolfe 2008).

The above example demonstrates, yet again, that such relations are flexible: They are not based on the intrinsic essential qualities of a species, but rather on how they are arranged and what they create in specific contexts and situations. Also evident in the extract is the particular being's significance for the possibility of an ethically responsible relationship, for a place ‘where someone comes into presence’ (Biesta 1999, 209). It is thereby in a specific, particular encounter that an encounter that 'resists codification' (Todd 2008, 9) might be possible. The encounter that occurs beyond codification and appropriation happens beyond the compelling framework of knowledge. Knowledge is not a requirement for enabling an ethical relationship with the other. Instead, knowledge and the need to know, categorize, and organize present an obstacle to, or even rule out, entering into an ethical relationship with something fundamentally different from oneself. Educational philosopher Todd (2003, 52-53) speaks of the ethical potential in unknowability. The pig cadavers in the photo that are suddenly reterritorialized - that is, they go from being a product in a factory to being 
once more associated with a living being that can suffer (see, e.g., Wolfe $[2008,120])$ indicate, however, that a lack of knowledge also risks causing devastating consequences for certain bodies in this relationship.

The possibility of ignoring the everyday lives of the pigs limits the possibility of developing ethically responsible knowledge. Derrida (cited by Wolfe [2008]) teaches us that the visible can produce blindness by making the seeing subject unable to grasp the non-visible. Derrida connects the understanding of the subject as semiotically organized to 'not-seeing' (Wolfe 2008, 113). Knowledge can therefore be seen as both an opportunity for and an obstacle to creating ethical relationships involving human and nonhuman animals. As Lorimer (2007) points out in his analysis of nonhuman charisma, many species for various reasons will never achieve the status of symbols/icons. This means that they are excluded from discourses of diversity and conservation.

The next focus group excerpt contains another discussion of the previously discussed illustration shown to the participants to stimulate discussion. The choice of stimulus material allowed participants to visually encounter an everyday situation for pigs in our society, where many pig lives are produced in industrial complexes:

Gert: I usually talk about this sort of thing [points at the image of the pigs] when it deals with how we use animals, how we travel around in other cultures. For example, when you travel to China and order a duck, the duck is brought in with its head still there, so you really get to see what this thing really was.

Göran: You can’t cheat then and say that ((laughter))

Gert: No, but we have a completely different understanding. We don't want to see what it is. Instead, it is a bit like there is some meat factory somewhere where meat grows. 
The fact that it involves animals is not at all part of our mental picture.

Jenni $(2005,1)$ writes that 'we respond in dramatically different ways to suffering we see'. The excerpt above treats at least two significant human-animal relationships: the one between Gert and the pigs in the image, and the one between Gert and the duck on his plate. In both relationships, Gert is compelled to respond to the Other's situation. The image of the pigs, which many participants found disturbing, seems to reterritorialize the pork on the plate, i.e. it goes from being something other than its deterritorialized self to becoming what it once was. The meat on the plate is given a 'face' to which Gert must respond in some way. The duck's face on the plate, in a literal sense, makes it impossible for Gert to disregard the fact that what is about to be eaten was once someone. The reterritorialization of the relationship ordered the knowledge so that the possibility of responding could emerge.

Once more, we hold, following Todd (2003, 9), that the aforementioned relationships in which Gert participates can be regarded as among the temporary 'relational moments which resist codification'. What we mean here is simply that number interacts with reterritorialization. The pigs in the excavator and the duck on the plate create elements to which Gert and his focus group colleagues respond, thereby becoming other people - people who respond.

It is problematic, however, to confront elements that do not lend themselves to being ordered within the frame of previous experience and encounters. In the discussion below, participants in one focus group explain their negative reactions to the picture of the pigs: 
Hanna: You mentioned a picture here.

Nancy: I mentioned a picture here and this is what I thought: I could conceivably use all these pictures, but I don’t think I would want to use this picture of the pigs, especially not to introduce sustainable development, because I think that it is so negative. It is so extremely negative and it would be such an unamusing introduction to sustainable development. It evokes such negative reactions that I don’t think that I would use the picture, at least not at first. That was it.

Nils: Actually, I agree completely. We should not fall into the trap of speaking only of environmental problems, because they actually have nothing to do with sustainable development.

Nancy's reaction to the image of the pigs illustrates the problem of allowing latitude for the unknown as an educator. Nancy and Nils speak of this danger when referring to an ‘unamusing introduction' to sustainable development. The reterritorialization that emerges in the encounter with the image of the pigs challenges the teacher instructors by restructuring the relationships and creating something new and different - pigs as subjects. The ‘negative reactions' about which Nancy is concerned could clearly challenge the prevailing view of how pigs live and die, and of their well-being in our society.

Pedersen (2011) has noted a glimmer of hope in people's interest in witnessing the dairy company Arla's yearly betessläppet (cow release) in spring. The cow release is an event that Swedish farmers invite the public to watch, as they let their cows out to graze after several months in the barn. Despite the violence and control to which the cows are subjected, people’s broad interest in betessläppet suggests new possibilities for ethical relationships with cows (Pedersen 2011, 78). The dead pigs in the picture, in relation to 
the participating teachers, both facilitate and impede their responding to the other. The reterritorialization of the duck on the plate challenges a boundary that the relationship with a deterritorialized, headless duck does not challenge. Reterritorialization enables individual responsibility while making it difficult to feel responsibility for a collective's health and well-being. This problem can be seen as connected to the problematic logic of the zoo, as outlined earlier. The logic that permits caring for one or two caged animals to benefit the greater collective of an endangered species is highly problematic: One suffers for many, or many are ignored in favour of an individual.

\section{Conclusions: sustainability education beyond the zoo?}

We began this paper by outlining why today's environmental challenges require theoretical and methodological tools that can help us think in various ways about issues concerning boundaries and relationships in sustainability education. By examining focus group conversations that addressed both human and nonhuman bodies, we identified and provided examples of two ordering mechanisms - individualization and reterritorialization. These two modes delimit responsible knowledge, which we claim is significant in shaping what is possible in sustainability education. The examined human-animal relationships have consequences for the kind of knowledge considered important in education fostering more sustainable societies.

We have elucidated and critiqued individuality as operative in bringing together knowledge and responsibility. In the case of relations that move between the general and specific, the boundaries are redrawn, with consequences for who - or what - lives and who dies. Second, we have elucidated and critiqued reterritorialization as significantly shaping the possibilities to respond. Both of these circumstances interact and are influenced by material and discursive conditions located between the dualisms 
that characterize Western knowledge production.

As Levinas and Nemo (1985) and Haraway (2008) point out, “being” occupies a crucial political dimension. It is important to pay attention to the detailed path by which something or someone comes into "being”, becomes a subject. Taking up this argument, Wolfe (2008) claims that the model of the subject that dominates the liberal democratic framework is based on the logic of sameness rather than difference. Those who are not granted agency in the liberal sense, such as disabled people and nonhuman animals, gain rights based solely on the argument that they are 'diminished versions of us' (118) instead of being recognized for having unique forms of subjectivity.

The empirical examples from the focus groups illustrate moments when the educational relationships and boundaries seem negotiable and possible to change. These examples merit emphasis because the boundaries of such relationships are significant in addressing the painful question of who - or what - gets to live and who gets to die. Haraway $(2008,80)$ holds that 'it is not killing that gets us into extremism, but making beings killable'. The distinction between killing and making others killable is vital in preventing us from falling into the trap of relativism. When killing is part of being, one must situate being in specific practices, discourses, and places beyond the dreams of a universal morality and ethics. Responsibility for the Other is, as Levinas and Nemo (1993, 114) point out, ‘a non-symmetrical relationship’. We suggest that a theoretical arsenal is needed in order to scrutinize the relationship between knowledge and the boundaries of the possibility of becoming in education.

By combining feminist posthumanities and educational discussions of ethics, responsibility, and subjectivity, we have demonstrated that educational responsibility needs to be more inclusive in the realm of sustainability. The ordering mechanisms of 
individuality and reterritorialization are limited when it comes to generating responsible knowledge that includes nonhuman life. These mechanisms pose a problem that needs to be discussed and paid more attention: The earth's ecological crises require responsibility that goes beyond the individual encounter and the reterritorialization of others: the current crises undoubtedly also involve the 'faceless' Others whose lives and health affect us all. Philosopher Judith Butler (2006, xviii) writes: 'Those who remain faceless ... authorize us to become senseless before those lives we have eradicated, and whose grievability is indefinitely postponed'. This is where it is important to highlight and study the relations and boundaries that constantly create inclusions and exclusions, with consequences for who - or what - gets to live and who gets to die. Butler helps us understand that grief at the loss of Others does not disappear, but is only postponed to an undefined future. The loss of species and ecosystems continues to affect us long after their extinction because, as Alaimo (2008, 2010, 2011) points out, the human body overlaps other human bodies, nonhuman beings, and physical landscapes. As we see it, the real challenge in bringing together posthumanities interventions and educational questions is both to recognize radical difference as a basis for ethical relationships, and to strive to dissolve boundaries as an ethical project. To do this, educational theory and practice need to rethink subjectivity outside the realm of the human animal.

We have used the metaphor of the zoo when analysing the teacher instructors' conversations, and we suggest that education promoting sustainable development needs to be rethought outside the logic of the zoo. Challenging preconceived notions of education in this way is important at a time when teacher instructors face the task of training future generations in addressing the earth’s ecological crises. In school and education - which the United Nations and other institutions have declared important arenas in achieving more sustainable development - the questions of what knowledge is 
and what knowledge is valid are constantly negotiated. These negotiations are about whose lives are important. When we regard animals as more than 'fun-house reflections of ourselves', it will be possible to step out of the zoo and recognize how intertwined and interdependent human and nonhuman animals truly are.

\section{References}

Alaimo, Stacy. 2008. “Trans-Corporeal Feminism and the Ethical Space of Nature.” In Material Feminisms, edited by Stacy Alaimo and Susan J. Hekman, 237-264. Bloomington, IN: Indiana University Press.

Alaimo, Stacy. 2010. Bodily Natures: Science, Environment, and the Material Self. Bloomington: Indiana University Press.

Alaimo, Stacy. 2011. "Det nakna ordet: Den protesterande kroppens transkorporala etik.” [The Naked Word: The Protesting Body's Trans-Corporeal Ethics.] Tidskrift för genusvetenskap, no. 4: 29-58.

Alaimo, Stacy. 2012. "Sustainable This, Sustainable That: New Materialisms, Posthumanism, and Unknown Futures.” PMLA 127 (3): 558-564. doi:10.1632/pmla.2012.127.3.558.

Badmington, Neil. 2004. “Mapping posthumanism.” Environment and Planning A 36: 1344-1351.

Barad, Karen. 2003. "Posthumanist Performativity: Toward an Understanding of How Matter Comes to Matter.” Signs 28 (3): 801-31.

Best, Steve, Anthony J. Nocella, Richard Kahn, Carol Gigliotti, and Lisa Kemmerer. 2007. ”Introducing Critical Animal Studies.” Animal Liberation Philosophy and Policy Journal 5 (1): 4-5.

Biesta, Gert. 1999. "Radical intersubjectivity: Reflections on the 'Different' Foundation of Education.” Studies in Philosophy and Education 18 (4): 203-220.

Biesta, Gert. 2006a. Bortom lärandet: Demokratisk utbildning för en mänsklig framtid [Beyond Learning: Democratic Education for a Human Future]. Translated by Gunnar Sandin. Lund: Studentlitteratur.

Biesta, Gert. 2006b. Beyond Learning: Democratic Education for a Human Future. Boulder: Paradigm Publishers.

Birke, Lynda. 2012. “Unnamed Others: How Can Thinking about 'Animals’ Matter to Feminist Theorizing?” NORA - Nordic Journal of Feminist and Gender Research 20 (2): 148-57. doi:10.1080/08038740.2012.674059. 
Bodén, Linnea. 2013. "Seeing Red? The Agency of Computer Software in the Production and Management of Students' School Absences.” International Journal of Qualitative Studies in Education 26 (9): 1117-1131. doi:10.1080/09518398.2013.816887.

Braidotti, Rosi. 2013. The Posthuman. Cambridge: Polity.

Brando, Sabrina and Jess Lynning Harfeld. 2014. "Eating Animals at the Zoo.” Journal for Critical Animal Studies 12 (1): 63-88.

Buber, Martin. 1970. I and Thou. Translated by Walter Kaufmann. New York, NY: Simon \& Schuster.

Buber, Martin. 1994. Jag och Du [I and Thou]. Translated by Curt Norell and Margit Norell. Ludvika: Dualis.

Butler, Judith. 2006. Precarious Life: The Powers of Mourning and Violence. London: Verso.

Calvo, Erika. 2008. “'Most Farmers Prefer Blondes’: The Dynamics of Anthroparchy in Animals’ Becoming Meat.” Journal for Critical Animal Studies VI (I): 32-45.

Colebrook, Claire. 2010. Gilles Deleuze: En introduktion [Gilles Deleuze : An Introduction]. Translated by Victor Andreasson and Mikael Müller. Göteborg: Korpen.

Drevfjäll, Ann-Katrin. 2013. “Föräldrar Arga: 'Man Behöver Kött'.” [Parents Angry: 'One Needs Meat'.] Södermanlands Nyheter, August 30. http://www.sn.se/nyheter/nykoping/1.1892582.

Gough, Noel. 2004. "RhizomANTically Becoming-Cyborg: Performing Posthuman Pedagogies.” Educational Philosophy and Theory 36 (3): 253-265. doi:10.1111/j.1469-5812.2004.00066.x.

Gough, Stephen, and William Scott. 2008. Higher Education and Sustainable Development: Paradox and Possibility. Abingdon: Routledge.

Gålmark, Lisa. 2005. Skönheter och odjur : En feministisk kritik av djur-människarelationen [Beauty and the Beasts: A Feminist Critique of the Animal-HumanRelation]. Göteborg: Makadam.

Haraway, Donna. 1992. "The Promises of Monsters: A Regenerative Politics for Inappropriate/d Others.” In Cultural Studies, edited by Lawrence Grossberg, Cary Nelson, and Paula A. Treichler, 295-337. New York: Routledge.

Haraway, Donna. 2008. When Species Meet. Minneapolis: University of Minnesota Press.

Heise, Ursula K. 2008. Sense of Place and Sense of Planet : The Environmental Imagination of the Global. Oxford: Oxford University Press. 
Hinchliffe, Steve, Matthew B. Kearnes, Monica Degen, and Sarah Whatmore. 2005. "Urban Wild Things: A Cosmopolitical Experiment." Environment and Planning D: Society and Space 23 (5): 643 - 658. doi:10.1068/d351t.

Hultman, Karin, and Hillevi Lenz Taguchi. 2010. "Challenging Anthropocentric Analysis of Visual Data: A Relational Materialist Methodological Approach to Educational Research.” International Journal of Qualitative Studies in Education (QSE) 23 (5): 525-542.

Jenni, Kathie. 2005. “The Power of the Visual.” Animal Liberation Philosophy and Policy Journal III (I): 1-21.

Kahn, Richard. 2003. "Towards Ecopedadogy: Weaving a Broad-based Pedagogy of Liberation for Animals, Nature, and the Oppressed People of the Earth.” Journal for Critical Animal Studies 1(1): 35-

52. http://richardkahn.org/writings/ecopedagogy/towardsecopedagogy.pdf.

Kitzinger, Jenny, and Rosaline S. Barbour. 1999. "Introducation: The Challange and Promise of Focus Groups.” In Developing Focus Group Research : Politics, Theory and Practice, edited by Rosaline S. Barbour and Jenny Kitzinger, 1-20. London: SAGE.

Kjöller, Hanne. 2012. "Feltänkt Gånger Sex.” [Wrong Thinking Multiplied by Six.] Dagens Nyheter, September 2. http://www.dn.se/ledare/signerat/feltankt-gangersex/.

Levinas, Emmanuel, and Philippe Nemo. 1985. Ethics and Infinity. Pittsburgh: Duquesne University Press.

Levinas, Emmanuel, and Philippe Nemo. 1993. Etik och oändlighet: Samtal med Philippe Nemo [Ethics and Infinity: Conversations with Philippe Nemo]. Translated by Maria Gunnarsson Contassot. Stockholm: B. Östlings bokförlag Symposion.

Lorimer, Jamie. 2007. “Nonhuman Charisma.” Environment and Planning D: Society and Space 25 (5): 911-932. doi:10.1068/d71j.

Lykke, Nina. 2009. "Non-Innocent Intersections of Feminism and Environmentalism.” Kvinder, køn og forskning 18 (3-4): 36-44.

Lykke, Nina. 2010. Feminist Studies: A Guide to Intersectional Theory, Methodology and Writing. London: Routledge.

Marino, Lori, Gay Bradshaw, and Randy Malamud. 2009. "The Captivity Industry: The Reality of Zoos and Aquariums.” Best Friends Magazine Mar./Apr.: 25-27.

McNaughton, Marie Jeanne. 2010. "Educational Drama in Education for Sustainable Development: Ecopedagogy in Action.” Pedagogy, Culture \& Society 18 (3): 289-308. doi:10.1080/14681366.2010.505460. 
Nibert, David. 2003. "Humans and Other Animals: Sociology’s Moral and Intellectual Challenge.” International Journal of Sociology and Social Policy 23 (3): 4-25. doi:10.1108/01443330310790237.

Nocella, Anthony J., John Sorenson, Kim Socha, and Atsuko Matsuoka. 2014. "Introduction: The Emergence of Critical Animal Studies.” In Defining Critical Animal Studies: An Intersectional Social Justice Approach for Liberation, edited by Anthony J. Nocella, John Sorenson, Kim Socha, and Atsuko Matsuoka, xixxxxvi. New York: Peter Lang.

Olsson, Eva. 2012. “Köttfri dag i Östersund möter motstånd.” [Meat Free Day in Östersund Meets Resistance.] Fria Tidningen, September 13. http://www.fria.nu/artikel/92571.

Pedersen, Helena. 2007. "The School and the Animal Other: An Ethnography of Human-Animal Relations in Education.” PhD diss., University of Gothenburg.

Pedersen, Helena. 2010a. "Education Policymaking for Social Change: A PostHumanist Intervention.” Policy Futures in Education 8 (6): 683-696. doi:10.2304/pfie.2010.8.6.682.

Pedersen, Helena. 2010b. "Is 'the Posthuman' Educable? On the Convergence of Educational Philosophy, Animal Studies, and Posthumanist Theory.” Discourse: Studies in the Cultural Politics of Education 31 (2): 237-250.

Pedersen, Helena. 2011. "Release the Moths: Critical Animal Studies and the Posthumanist Impulse.” Culture, Theory and Critique 52 (1): 65-81. doi:10.1080/14735784.2011.621663.

Redmalm, David. 2011. "In-Your-Face Ethics: On the Phenomenology of the Face and Social Psychological Animal Studies.” In Undisciplined Animals: Invitations to Animal Studies, edited by Pär Segerdahl, 73-104. Newcastle upon Tyne: Cambridge Scholars Publishing.

Skolverket (The Swedish National Agency for Education). 2011. Läroplan för grundskolan, förskoleklassen och fritidshemmen [Curriculum for the Compulsory School, Preschool Class and the Recreation Centre]. Stockholm.

Solot, Dorian, and Arnold Arluke. 1997. "Learning the Scientist's Role: Animal Dissection in Middle School.” Journal of Contemporary Ethnography 26 (1): 28-54. doi:10.1177/089124197026001002.

Todd, Sharon. 2003. Learning from the Other : Levinas, Psychoanalysis, and Ethical Possibilities in Education. Albany: State University of New York Press.

Todd, Sharon. 2008. Att lära av den Andre : Levinas, psykoanalys och etiska möjligheter i undervisning och utbildning [Learning from the Other : Levinas, Psychoanalysis, and Ethical Possibilities in Education]. Translated by Gunnar Sandin. Lund: Studentlitteratur. 
UNESCO (United Nations Educational, Scientific and Cultural Organization). 2013. "Education for Sustainable Development (ESD)." Accessed December 16. http://www.unesco.org/new/en/education/themes/leading-the-internationalagenda/education-for-sustainable-development/.

Vygotsky, Lev. 1994. Thought and Language. London: The MIT Press.

Wibeck, Victoria. 2010. Fokusgrupper: Om fokuserade gruppintervjuer som undersökningsmetod [Focus Groups: On Focused Group Interviews as Research Method]. Lund: Studentlitteratur.

Wibeck, Victoria, Madeleine Abrandt Dahlgren, and Gunilla Öberg. 2007. "Learning in Focus Groups.” Qualitative Research 7 (2): 249-267. doi:10.1177/1468794107076023.

Willis, Susan. 1999. “Looking at the Zoo.” The South Atlantic Quarterly 98 (4): 669687.

Weisberg, Zipporah. 2009. “The Broken Promises of Monsters: Haraway, Animals and the Humanist Legacy.” Journal for Critical Animal Studies VII (II): 22-69.

Wolfe, Cary. 2008. "Learning from Temple Grandin, Or, Animal Studies, Disability Studies, and Who Comes after the Subject.” New Formations, no. 64: 110-124. Literature Resource Center.

Wolfe, Cary. 2010. What Is Posthumanism? Minneapolis: Minn. University of Minnesota Press.

Åsberg, Cecilia, Redi Koobak, and Ericka Johnson. 2011. “Post-Humanities Is a Feminist Issue.” NORA - Nordic Journal of Feminist and Gender Research 19 (4): 213-16. doi:10.1080/08038740.2011.625369.

Åsberg, Cecilia. 2012. "Läskunnighet bortom humanioras bekvämlighetszoner. En Inledning.” [Literacy beyond the Comfort Zones of the Humanities. An Introduction.] In Posthumanistiska Nyckeltexter [Key Works of the Posthumanities], edited by Cecilia Åsberg, Martin Hultman, and Francis Lee, 721. Lund: Studentlitteratur. 